\title{
Techniques to Minimize the Effects of Acute Heat Stress or Chronic in Broilers
}

http://dx.doi.org/10.1590/1806-9061-2018-0962

\section{-Author(s)}

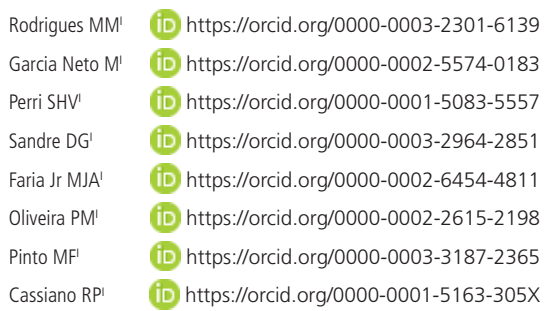

UNESP - Departamento de Apoio, Produção e Saúde Animal - DAPSA - Rua Clóvis Pestana, 793 - Bairro: Ipanema, Araçatuba, São Paulo 16050 680 , Brazil.

\section{Mail Address}

Corresponding author e-mail address Manoel Garcia Neto

UNESP - Departamento de Apoio, Produção e Saúde Animal - DAPSA - Rua Clóvis Pestana, 793 - Bairro: Ipanema, Araçatuba, São Paulo 16050-680, Brazil. Phone: +55(18)3636-1368 Email: m.garcia@unesp.br

\section{- Keywords}

Animal nutrition, broilers, electrolyte balance, pale muscle syndrome, temperature.

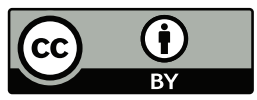

Submitted: 06/December/2018 Approved: 23/April/2019

\section{ABSTRACT}

High environmental temperature is limiting factor in broiler production. In order to minimize the undesirable consequences of acute or chronic heat stress, the techniques of fixed dietary electrolyte balance and early heat conditioning were evaluated. The objective of this study was to evaluate the possible interactions and effects of dietary electrolyte balance and early heat conditioning on feed intake, body weight, feed conversion ratio, mortality, energy bioeconomic index, fecal moisture, abdominal fat, and breast meat color $\left(L^{*} a^{*} b^{*}\right)$ of broilers submitted to chronic or acute heat stress. In total, 1280 chicks, were equally divided in experiment I (chronic heat stress, $6 \mathrm{~h} /$ day at $32^{\circ} \mathrm{C}$ from 35 to $39 \mathrm{~d}$ of age) and II (acute heat stress, $36^{\circ} \mathrm{C}$ for $6 \mathrm{~h}$ at 38 days of age). The data of both experiments were combined and analyzed according to a $2 \times 2 \times 2$ factorial arrangement (early heat conditioning (ETC) or not; fixed dietary electrolyte balance (EB) or not; and exposure to acute or chronic heat stress). ETC consisted of exposing 5-d-old birds to $36.0^{\circ} \mathrm{C}$ for 24 hours. No interaction among the evaluated factors was detected. Birds exposed to acute heat stress presented significantly higher compared with chronic heat stress. Fixed dietary EB resulted in significantly higher fecal moisture. Lower abdominal fat percentage was obtained in birds exposed to chronic relative to acute heat stress. Higher breast meat $L^{*}$ and $b$ * values were observed in birds exposed to acute heat stress than those submitted to chronic heat stress, indicating worse meat quality.

\section{INTRODUCTION}

One of the main challenges in commercial broiler production is heat stress and its economic consequences, as it reduces growth rate and feed intake, and increases mortality (Mujahid, 2011). The expansion of the poultry industry to tropical regions has stimulated the search for methods to alleviate the consequences of heat stress (Zaboli et al., 2017). Although Brazil is the world's second largest chicken meat producer, with 13.05 million tons (ABPA, 2018) and has a promising market, its tropical climate, with high temperatures and high relative humidity, poses a continuous challenge to live broiler performance.

The expansion of the poultry industry to tropical regions has stimulated the search for methods to alleviate the consequences of heat stress (Zaboli et al., 2017). The acclimation of birds, dietary and/or drinking water management, the use of antipyretic drugs and ascorbic acid, as well as the manipulation of dietary protein, energy and major electrolyte levels have been employed (Borges et al., 2003).

Heat stress causes several metabolic changes in broilers, including acid-base imbalance. In an attempt to prevent such effects and to improve animal performance, Gamba et al. (2015) suggested that 
Rodrigues MM, Garcia Neto M, Perri SHV, Sandre DG, Faria Jr MJA, Oliveira PM, Pinto MF, Cassiano RP
Techniques to Minimize the Effects of Acute Heat Stress or Chronic in Broilers diets should be formulated with adequate electrolyte levels and ratios aiming at obtaining appropriate electrolyte balance. There are few literature reports on the potassium $(\mathrm{K})$, chorine $(\mathrm{Cl})$, and sodium $(\mathrm{Na})$ ratio for broilers, expressed as $\left(\left[\mathrm{K}^{+}\right]+\left[\mathrm{Cl}^{-}\right]\right) /\left[\mathrm{Na}^{+}\right]$(Ahmad \& Sarwar, 2006), although this concept had already been proposed in 1981 by Mongin (1981), possibly due to the complexity of its calculation in feed formulation. However, the Solver tool of the Microsoft ${ }^{\circledR}$ Excel spreadsheets allows introducing the mathematical equations required to calculate both electrolyte balance and ratio (ER) during feed formulation (Garcia Neto, 2008).

Broilers can also be physiologically manipulated to better tolerate heat stress using acclimation or heat conditioning. By exposing broilers to constant high environmental temperature, acclimation promote heat tolerance; however, it impairs live performance. On the other hand, thermal conditioning by short-term exposure of chicks to high temperatures during the first week of age results in thermotolerance and maintains the growth rate, but depends on compensatory weight gain (Yahav \& McMurtry, 2001).

The objective of this study was to evaluate the possible interactions between early thermal conditioning (ETC) and diet formulation considering electrolyte balance (EB) on the performance, carcass traits, as well as their economic viability in broilers submitted to acute or chronic heat stress.

\section{MATERIALS AND METHODS}

The study was carried out in accordance with the Ethical Principles of Animal Experimentation (COBEA) and approved by Animal Ethics Committee, under process n. 00887-2012.

Two experiments were performed. Each evaluated 640 Cobb 500 male broilers from 1 to 42 days of age. In experiment I, birds were submitted to chronic heat stress, and to acute stress in experiment II; both were applied in the final third of the rearing period.

One-day-old broilers were weighed and randomly distributed in metal cages with 20 birds each. Each cage was equipped with an automated heating source (60W bulb). At 5 days of age, half of the flock of each experiment (320 birds from experiment I and 320 from experiment II) was submitted to the Early Heat conditioning (ETC), which consisted of exposing the birds to a temperature of $36^{\circ} \mathrm{C}$ for 24 hours in their original cages. The other half was placed in the rearing shed.
On d 6, all birds were placed in an environmentallycontrolled masonry shed, with an adiabatic evaporative cooling system, negative pressure ventilation, and wood-shavings litter. Water and feed were provided ad libitum.

A 3-phase feeding regime was applied (starter, grower, and finisher diets). The diets were formulated considering fixed electrolyte balances (EB) and ratios (ER) or not (conventional diets). Dietary electrolyte balance was calculated as $\mathrm{EB}=\mathrm{Na}^{+}+\mathrm{K}^{+}-\mathrm{Cl}^{-}$and electrolyte ratio as $E R=\left(\mathrm{K}^{+}+\mathrm{Cl}^{-}\right) / \mathrm{Na}^{+}$, according to Mongin (1981). The following values were considered in the formulation: $E B=250 \mathrm{mEg} / \mathrm{kg}$ and $E R=3: 1$ in the starter diet, and $E B=300 \mathrm{mEq} / \mathrm{kg}$ and $E R=3: 1$ in the grower and finisher diets (Table 1).

The treatments consisted of the combination or not of dietary electrolyte balance (EB), early heat conditioning (ETC) and exposure to chronic (Exp. I) or acute (Exp. II) heat stress (Table 2).

In experiment I, birds were submitted to chronic heat stress, which consisted of exposure to an average temperature of $32^{\circ} \mathrm{C}$ for $6 \mathrm{~h} / \mathrm{d}$ from 35 to 39 days of age. In experiment II, the birds were submitted to acute heat stress, which consisted of exposure to an average temperature of $36^{\circ} \mathrm{C}$ for $6 \mathrm{~h}$ at 38 days of age. These temperatures were obtained by switching off the cooling system and turning on the heating system (Gonzalez-Esquerra \& Leeson, 2005).

As no interaction between treatments and experiments $(p>0.05)$ was detected, the data from experiment I and II were combined according to the procedure adopted by Cromwell et al. (1995). A number of 1,280 broiler was distributed according to a completely randomized experimental design in $2 \times 2 \times 2$ a factorial arrangement (ETC or not, diets with fixed EB or not, and exposure or not to chronic or acute heat stress), totaling eight treatments, with eight replicates each.

On day 42 , corrected feed intake ( $\mathrm{kg} / \mathrm{bird} /$ period), corrected feed conversion ratio ( $\mathrm{kg}$ of feed/ $\mathrm{kg}$ body weight) and weight gain ( $\mathrm{kg} / \mathrm{bird} /$ period) were evaluated. Birds were observed twice daily (morning and afternoon), and all mortality was accounted for the correction of feed intake and feed conversion ratio.

The economic viability of the experimental diets was determined by the Bioeconomic Energy Conversion Index (BEC) (Garcia Neto et al., 2013), according to the equation below. It is based on the total weight of the flock ( $\mathrm{kg}$ live birds at the end of the production cycle) and not average weight, and, therefore, allows taking into account mortality (Figure 1). 
Rodrigues MM, Garcia Neto M, Perri SHV, Sandre DG, Faria Jr MJA, Oliveira PM, Pinto MF, Cassiano RP
Techniques to Minimize the Effects of Acute Heat Stress or Chronic in Broilers

Table1 - Composition and cost of the diets fed to the broiler during experiments I and II according to rearing stage.

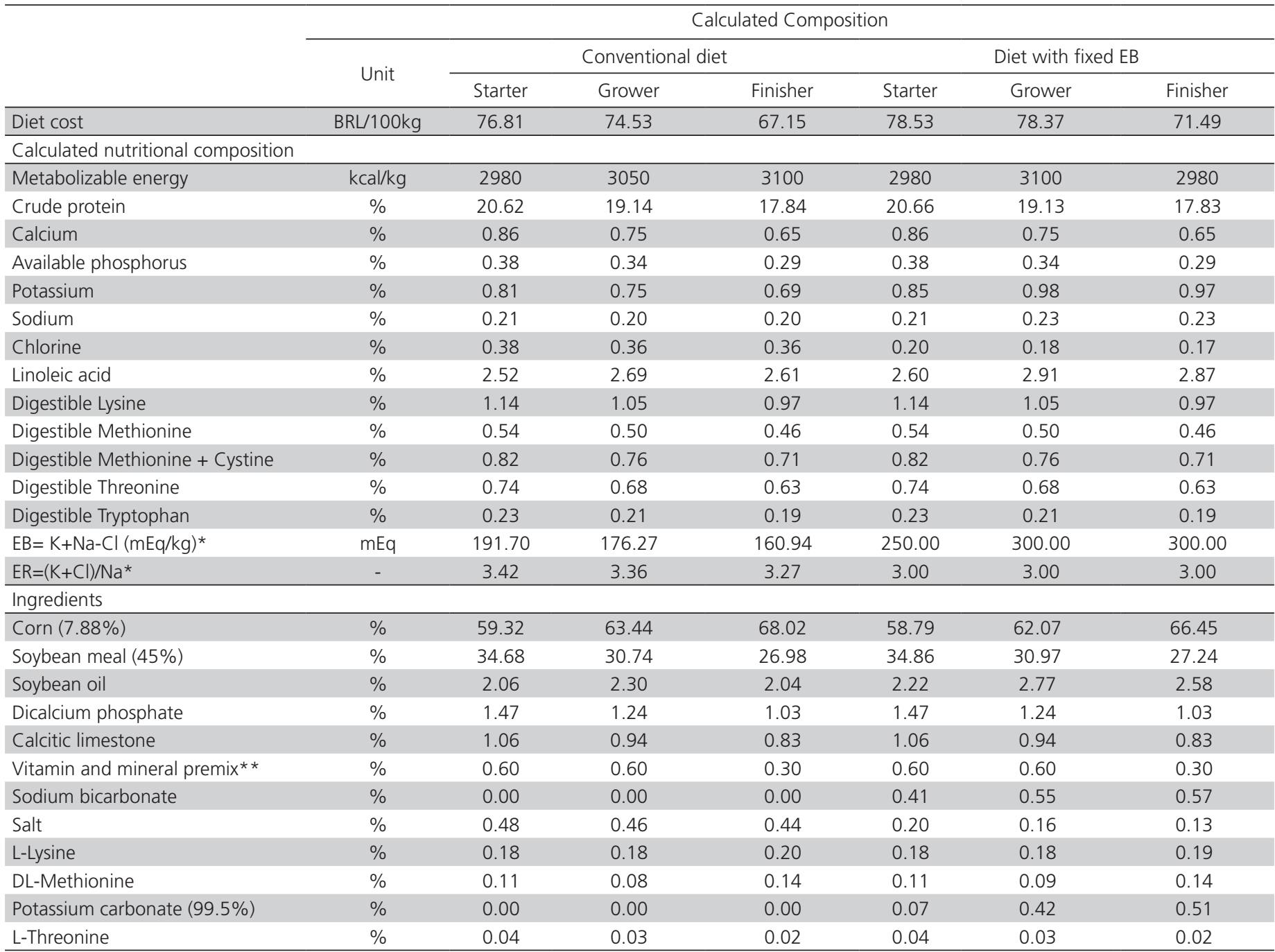

${ }^{*} \mathrm{~EB}=$ electrolyte balance; $\mathrm{ER}=$ electrolyte ratio

${ }^{* *}$ Composition per kg of product: Starter diets: Vit. A - 1670,000 IU; Vit. E - 2.500 mg; Vit. K3 - 417 mg; Vit. B1 - 250 mg; Vit. B2 - 835 mg; Vit. B6 - 250 mg; Vit. B12 - 2,000 mg; Folic acid - 100 mg; Biotin - 9 mg; Niacin - ,835 mg; Calcium pantothenate - 1,870 mg; Cu - 1,000 mg; Co - 17 mg; I 170 mg; Fe - 8,335 mg; Mn - 10,835 mg; Zn - 7,500 mg; Se - 35 mg; Choline chloride 50\% - 116,670 mg; Methionine - 250,000 mg; Coccidiostat - 13,335 mg; Growth promoter - 13.335 mg; Antioxidant - 2000 mg. Grower diet: Vit. A -1,335,000 IU; Vit. D3 - 300,000 IU; Vit. E -2.000 mg;Vit. K3 -335 mg; Vit. B1 - 167 mg;Vit. B2 - 670 mg; Vit. B6 - 170 mg;Vit. B12 - 1,670 mg; Folic acid - 67 mg; Biotin - 7 mg; Niacin - 4.670 mg; calcium pantothenate - $1.870 \mathrm{mg}$; Cu - 1,000 mg; Co - 17 mg; I - 170 mg; Fe - 8,335 mg; Mn - 10,835 mg; Zn - 7,500 mg; Se - 35 mg; Choline chloride 50\% - 83,340 mg; Methionine - 235,000 mg; Coccidiostat - 10,000 mg; Growth promoter - 10,000 mg; Antioxidant - 2,000 mg. Finisher diet: Vit. A - 1670,000 IU; Vit. D3 - 335.000 mg; Vit. E - 2,335 mg Vit. K3 - 400 mg; Vit. B1 - 100 mg; Vit. B2 - 800 mg; Vit. B6 - 200 mg; Vit. B12 - 2,000 mg; Folic acid - 67 mg; Biotin - 7 mg; Niacin - 5,670 mg; Calcium pantothenate - 2,000 mg; Cu - 2,000 mg; Co - 27 mg; I 270 mg; Fe - 16,670 mg; Mn - 17,335 mg; Zn - 12,000 mg; Se - 35 mg; Choline chloride 50\% - 100,000 $\mathrm{mg}$; Methionine - 235,000 mg; Antioxidant - 2,000 mg.

Table 2 - Treatments evaluated in experiments I (chronic heat stress) and II (acute heat stress).

\begin{tabular}{lccc}
\hline Treatments & Heat stress ${ }^{1}$ & Fixed dietary electrolyte balance ${ }^{2}$ & Early thermal conditioning $^{3}$ \\
\hline A & & No & No \\
B & Chronic (I) & Yes & Yes \\
C & & No & Yes \\
D & Yes & No \\
\hline E & No & No \\
F & Acute (II) & Yes & Yes \\
G & & No & Yes \\
H & & Yes & No \\
\hline
\end{tabular}

${ }^{1}$ Chronic heat stress $-32^{\circ} \mathrm{C}$ for $6 \mathrm{~h} /$ day between 35 and 39 days of age; Acute heat stress $-36^{\circ} \mathrm{C}$ for $6 \mathrm{~h}$ at 38 days of age

${ }^{2}$ Fixed dietary electrolyte balance $(\mathrm{mEq} / \mathrm{kg}): \mathrm{EB}=\left(\mathrm{Na}^{+} / 22.99+\mathrm{K}^{+} / 39.10-\mathrm{Cl} / 35.45\right)^{*} 1000 ; \mathrm{ER}=\left[\left(\mathrm{K}^{+} / 39.10+\mathrm{Cl} / 35.45\right) /\left(\mathrm{Na}^{+} / 22.99\right)\right]$

${ }^{3}$ Early heat conditioning: at 5 days of age, birds were exposed to $36^{\circ} \mathrm{C}$ for 24 hours. 
Rodrigues MM, Garcia Neto M, Perri SHV, Sandre DG, Faria Jr MJA, Oliveira PM, Pinto MF, Cassiano RP

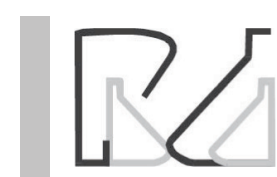

Techniques to Minimize the Effects of Acute Heat Stress or Chronic in Broilers

$$
B E C=\frac{[(a 1 . b 1 . c 1)+(a 2 . b 2 . c 2)+(a 3 . b 3 . c 3)]}{\text { d.e }} \text { Mcal / kg }
$$

Figure 1 - Improved BEC index equation

Where:

$\mathrm{a}=$ feed intake $(\mathrm{kg})$,

$\mathrm{b}=\operatorname{diet} \operatorname{cost}(\mathrm{R} \$ / \mathrm{kg})$,

$\mathrm{c}=$ dietary metabolizable energy content (Mcal $/ \mathrm{kg})$,

$\mathrm{d}=$ final flock weight $(\mathrm{kg})$,

$\mathrm{e}=$ price paid per $\mathrm{kg}$ of live chicken $(\mathrm{R} \$ / \mathrm{kg})$,

$1=$ starter phase

2 = grower phase

$3=$ finisher phase

Three birds per replicate (96 per experiment), which BW was representative of the average BW of the replicate, were stunned and sacrificed by bleeding. Carcasses were scalded, plucked, chilled, and eviscerated for determine fat and carcass weight.

The breasts were collected from the carcasses, deboned, the skin removed. Skinless and deboned breast samples $(\sim 200 \mathrm{~g})$ were submitted to color analysis at $4{ }^{\circ} \mathrm{C}$ (Woelfel et al., 2002), using a portable color spectrophotometer (Mini-Scan XE Plus, HunterLab, USA), calibrated with white and black standards. Breast color was determined according to the CIE $L^{*} a^{*} b$ * color system (Comission Internationale de l'Eclairage), where " $L$ " is luminosity $(0=$ black and $100=$ white), "a" is the red/green coordinate $(+a=$ red and $-a=$ green) and " $b$ " is the yellow/blue coordinate $(+b=$ yellow and $-b=$ blue $)$.

On day 42,32 fresh excreta samples $(\sim 10 \mathrm{~g})$ were collected per replicate for the evaluation of fecal moisture. Excreta samples were weighed, pre-dried in a forced-ventilation oven at $55^{\circ} \mathrm{C}$ for $72 \mathrm{~h}$, dried in forced-ventilation oven at $105^{\circ} \mathrm{C}$ for 12 hours, and then weighed in analytical precision Shimadzu scale (model bl-3200h, Japan), according to Silva \& Queiroz (2002).

Data were submitted to analysis of variance to verify the effect of treatments and to evaluate the effects of each factor, according to PROC GLM procedures of the SAS statistical package (SAS Institute, 2000). Means were compared by Student's t-test was applied, and significance was established at $5 \%$ probability level.

\section{RESULTS AND DISCUSSION}

The results of experiments I and II were combined because no significant interactions ( $p>0.05)$ between

Table 3 - Effects of the combination of experiments I and II (application of chronic and acute heat stress, respectively) on average feed intake (IF), weight gain (WG), feed conversion ratio (FCR), fecal moisture (FM), mortality, bioeconomic energy conversion index (BEC), abdominal fat weight (AFW), and breast meat color characteristics ( $L^{*} a^{*} b^{*}$ ) of 42-d-old male broilers.

\begin{tabular}{|c|c|c|c|c|c|c|c|c|c|c|}
\hline \multirow{3}{*}{ Factors } & \multirow{2}{*}{$\mathrm{Fl}(\mathrm{kg})$} & \multirow{2}{*}{ WG (kg) } & \multirow{2}{*}{ FCR } & \multirow{2}{*}{ FM (\%) } & \multirow{2}{*}{ Mortality (\%) } & \multirow{2}{*}{$\begin{array}{c}\mathrm{BEC}^{2} \\
(\mathrm{Mcal} / \mathrm{kg})\end{array}$} & \multirow{2}{*}{$\begin{array}{l}\text { AFW } \\
(\mathrm{g})\end{array}$} & \multicolumn{3}{|c|}{ Breast color $^{3}$} \\
\hline & & & & & & & & $L^{*}$ & $a^{*}$ & $b^{*}$ \\
\hline & \multicolumn{10}{|c|}{$\mathrm{Pr}>\mathrm{F}$} \\
\hline \multicolumn{11}{|c|}{ Fixed electrolyte balance (EB) } \\
\hline Yes & 5.71 & 3.42 & 1.81 & $81.70 \mathrm{a}$ & 34.81 & 3.11 & 91.48 & 62.40 & 8.18 & 20.60 \\
\hline No & 5.70 & 3.34 & 1.81 & $80.19 b$ & 33.88 & 2.73 & 89.91 & 61.97 & 8.25 & 20.21 \\
\hline \multicolumn{11}{|c|}{ Early thermal conditioning (ETC) } \\
\hline Yes & 5.74 & 3.37 & 1.82 & 80.66 & 36.06 & 2.98 & 92.23 & 62.36 & 8.19 & 20.62 \\
\hline No & 5.66 & 3.39 & 1.81 & 81.22 & 32.63 & 2.84 & 89.16 & 61.99 & 8.24 & 20.20 \\
\hline \multicolumn{11}{|l|}{ Heat stress } \\
\hline Chronic & 5.70 & 3.40 & 1.81 & 80.85 & $3.06 a$ & $1.74 \mathrm{a}$ & $53.90 \mathrm{a}$ & $57.66 \mathrm{a}$ & 8,06 & $17,64 \mathrm{a}$ \\
\hline Acute & 5.70 & 3.35 & 1.81 & 81.01 & $65.63 \mathrm{~b}$ & $4.20 \mathrm{~b}$ & $127.49 b$ & $66.40 \mathrm{~b}$ & 8,37 & $23,17 b$ \\
\hline $\mathrm{CV}(\%)$ & 9.26 & 7.22 & 8.77 & 3.17 & 37.31 & 44.13 & 13.91 & 3.86 & 11.74 & 5.61 \\
\hline ETC & 0.5443 & 0.7676 & 0.7415 & 0.3488 & 0.2879 & 0.6922 & 0.3327 & 0.2513 & 0.8391 & 0.1510 \\
\hline $\mathrm{EB}$ & 0.9397 & 0.2286 & 0.9495 & 0.0202 & 0.7709 & 0.1970 & 0.6189 & 0.4692 & 0.7891 & 0.1777 \\
\hline Thermal stress & 0.9998 & 0.4160 & 0.9983 & 0.8826 & $<0.0001$ & $<0.0001$ & $<0.0001$ & $<0.0001$ & 0.2064 & $<0.0001$ \\
\hline $\mathrm{ETC} * \mathrm{~EB}$ & 0.4931 & 0.6173 & 0.6592 & 0.0563 & 0.4734 & 0.2589 & 0.8509 & 0.5116 & 0.5074 & 0.3101 \\
\hline ETC *heat stress & 0.9308 & 0.9400 & 0.6059 & 0.6429 & 0.2879 & 0.7850 & 0.6756 & 0.0955 & 0.3855 & 0.1389 \\
\hline $\mathrm{EB} *$ heat stress & 0.7597 & 0.6718 & 0.9957 & 0.5500 & 0.4975 & 0.2832 & 0.4793 & 0.1179 & 0.5425 & 0.6909 \\
\hline $\mathrm{ETC}$ * EB * heat stress & 0.8384 & 0.2993 & 0.9683 & 0.7485 & 0.4051 & 0.2255 & 0.5381 & 0.2666 & 0.7660 & 0.1250 \\
\hline
\end{tabular}

'Means followed by the different letters in the same column within each factor are different by the Tukey's test at $5 \%$ probability level.

${ }^{2} \mathrm{BEC}$ (bioenergy conversion cost) $=[($ feed intake $(\mathrm{kg}) \times$ dietary metabolizable energy content $(\mathrm{Mcal} / \mathrm{kg}) \times$ diet cost $(\mathrm{R} \$ / \mathrm{kg})) /($ final flock weight $(\mathrm{kg}) \times$ price paid per $\mathrm{kg}$ of live chicken $(\mathrm{R} \$))]$

${ }^{3} L^{*}=$ lightness - express as a percentage (from 0 for black to 100 for white); $a^{*}=$ red/green coordinate: $+a=$ red, $-a=$ green; $b^{*}=$ yellow/blue coordinate: $+b=$ yellow, $-b=$ blue; Available at: htt0://sensing.konicaminolta.com.br/2013/11/entendendo-oespaco-de-cor-lab/\#sthash.5fVQkPAX.dpuf 
Rodrigues MM, Garcia Neto M, Perri SHV, Sandre DG, Faria Jr MJA, Oliveira PM, Pinto MF, Cassiano RP
Techniques to Minimize the Effects of Acute Heat Stress or Chronic in Broilers treatments and experiments were detected, i.e., the effects of the evaluated treatments were independent of the experiments (I and II). In addition, there was no interaction among or between the treatments. The treatments did not influence ( $p>0.05)$ feed intake, weight gain, or feed conversion ratio (Table 3 ).

The diets with fixed EB and the early heat conditioning were not effective in minimizing the effects of neither acute or chronic heat stress, as previously found by Oliveira et al. (2016) in a study with broilers subjected to chronic heat stress.

Fecal moisture was influenced only by dietary electrolyte balance $(p=0.0202)$, possibly due to the higher dietary levels of the ions $\mathrm{Na}^{+}$e $\mathrm{K}^{+}$(Table 1). Excessive $\mathrm{Na}^{+}$increases water consumption, whereas excessive $\mathrm{K}^{+}$results in increased urine output (Araújo et al., 2010), which may result in higher litter moisture. Borges et al. (2003) showed that the addition of potassium chlorine $(\mathrm{KCl})$ to the drinking water or diet promotes water consumption in broilers reared under heat stress. The addition of $\mathrm{KCl}$ is frequently recommended to increase water consumption of broilers under heat stress to support body heat loss mechanisms (Smith \& Teeter, 1987; Borges et al., 2003; Souza et al., 2002). However, as water consumption increases, there is a proportional increase in fecal moisture, leading to poor litter quality, and consequently, impairing broiler performance and making flock management more difficult (Gamba et al., 2015). Therefore, increased fecal moisture is related to excessive $\mathrm{Na}^{+}$and $\mathrm{K}^{+}$intake as well as to heat stress. When environmental temperatures are higher than upper thermal comfort limit $\left(18\right.$ to $20^{\circ} \mathrm{C}$ ), water consumption can reach 0.5 liters/bird/day. According to Teeter et al. (1985), higher water intake may be beneficial to broilers under heat stress conditions; however, in the present experiment, no such benefit was found in birds submitted to chronic heat stress.

The main reasons of the high dietary potassium content were possibly: 1) the main protein source of protein included on the experimental diets was soybean meal, which contains high potassium level (Araújo et al., 2010); and 2) and the inclusion of potassium carbonate in the experimental diets with fixed electrolyte balance $(E B=300 \mathrm{mEq} / \mathrm{kg}$ and $E R$ = 3). However, this did not occur in the starter feed, because $\mathrm{K}$ requirement was fixed in $\mathrm{EB}=250 \mathrm{mEq} / \mathrm{kg}$. Another possibility would be to use a different protein source with lower potassium concentration.

No interactions ( $p>0.05$ ) among the evaluated factors were detected for mortality, and there was no effect of ETC or diet on this parameter. However, mortality was 21.44 times higher $(p<0.001)$ in broilers submitted to acute heat stress $(65.63 \%)$ compared with those challenged with chronic stress (3.06\%). The high temperature $\left(36^{\circ} \mathrm{C}\right)$ to which birds were subjected during acute stress possibly caused heat shock, leading to death (Ludtke et al., 2010). During periods of heat stress, the body undergoes several metabolic and physiological changes as the birds attempt to stay alive; however, these changes are limited, and may cause death when overcome (Borges et al., 2003).

No interactions ( $p>0.05)$ among the evaluated factors were detected for the bioeconomic index, and there was no effect $(p>0.05)$ of ETC or diet on this parameter. On the other hand, worse BEI $(p<0.001)$ was calculated for the broilers submitted to acute heat stress (4.20) compared with those reared under chronic heat stress (1.74). This result is attributed to the higher mortality due to acute heat stress, as final body weight of the flock is considered in the calculation of the BEC index. These findings are in agreement with those reported by Deaton et al. (1986), Plavnik \& Yahav (1998), and Tabler et al. (2002), who showed that acute heat stress causes high mortality, and, consequently, high losses in the investments made in the production process of broilers and costs associated with the correct disposal of the dead birds.

No interactions ( $p>0.05)$ among the evaluated factors were detected for abdominal fat deposition ( $g$ ), and there was no effect ( $p>0.05$ ) of ETC or diet on this parameter. However, birds reared under chronic heat stress (127.5g) presented 2.37 times lower $(p<0,0001)$ abdominal fat weight than those submitted to acute heat stress (53.9g). This result may be explained by the utilization of body energy reserves (body fat) during the heat stress period. The behavioral responses of broilers to heat stress include erection of feather follicles and spreading wings of the body, increased consumption of cold water, panting, and drastically reduced feed intake (Teeter et al., 1985, Vale et al., 2010). Therefore, the longer the period of exposure to heat stress, the greater the utilization of energy reserves. In a study comparing chronic and acute heat stress in broilers, Xie et al. (2015) found that acute stress results in blood metabolism disorders, whereas chronic stress causes tissue damage due to the greater period of exposure the high temperatures.

Breast meat color was not affected ( $p>0.05)$ by the interactions among factors, nor by ETC and dietary fixed EB balance. The results show, however, lower $L^{*}$ and $b^{*}(p<0.0001)$ values in the breast meat of birds submitted to acute heat stress. In addition to the high mortality, acute heat stress resulted in pale breast 
Rodrigues MM, Garcia Neto M, Perri SHV, Sandre DG, Faria Jr MJA, Oliveira PM, Pinto MF, Cassiano RP
Techniques to Minimize the Effects of Acute Heat Stress or Chronic in Broilers meat, with mean $L^{*}$ value of 66.22 , consistent with the $L^{*}$ value previously found by Smith \& Northcutt (2009) in the breast meat of heat-shocked broilers (L $*=68.4$ ). Heat stress immediately prior to slaughter negatively affects the color of turkey meat (Ngoka \& Froning, 1982) and broilers (Northcutt et al., 1994). The present experiment confirmed that acute heat stress may impair chicken meat color. In addition, meat water holding capacity decreases as $L^{*}$ values increase, resulting in lower tenderness (Ludtke et al., 2010). Therefore, chicken breast meat with high $L$ * values are less tender and paler, which are undesirable from the consumer's perspective.

The results of this study show that feeding diets with fixed electrolyte balance (EB) and early thermal conditioning (ETC) were not effective in alleviating the negative effects caused by chronic and acute heat stress in broiler chickens. However, acute heat stress causes higher economic losses and poorer carcass quality compared with chronic heat stress in broilers.

\section{ACKNOWLEDGMENTS}

The authors thank the financial support granted by Fundação de Amparo à Pesquisa do Estado de São Paulo (FAPESP) under process number 13/09537-7.

\section{REFERENCES}

ABPA - Associação Brasileira de Proteína Animal. Relatório anual 2018; 2018 [cited 2018 Oct 18]. Available from: http://abpa-br.com.br/ storage/files/relatorio-anual-2018.pdf

Ahmad T, Sarwar M. Dietary electrolyte balance: implications in heat stressed broilers. World's Poultry Science Journal 2006;62(4):638-653.

Araújo WAG, Rostagno HS, Albino LFT, Carvalho T A, Neto ACR. Potássio na nutrição animal. Revista Eletrônica Nutritime 2010;7(4):1280-1291.

Borges SA, Maiorka A, Silva AVF. Fisiologia do estresse calórico e a utilização de eletrólitos em frangos de corte. Ciência Rural 2003;33(5):975-981.

Cromwell GL, Coffey RD, Parker GR, Monegue HJ, Randolph JH. Efficacy of a Recombinant-Derived Phytase in Improving the Bioavailability of Phosphorus in Corn-Soybean Meal Diets for Pigs. Journal of Animal Science 1995;73(7):2000-2008.

Deaton JW, Reece FN, Branton SL, May DJ. High environmental temperature and broiler livability. Poultry Science 1986;65(7):1268-1269.

Gamba JP, Rodrigues MM, Garcia Neto M, Perri SHV, Faria Júnior MJA, Pinto MF. The strategic application of electrolyte balance to minimize heat stress in broilers. Brazilian Journal of Poultry Science 2015;17(2):237246.

Garcia Neto, M. et al. Bio-energy conversion cost: a new index to evaluate the bioeconomic eficiency (Abstract - Int. Poultry Sci. Forum). Poultry Science 2013;92:255-255.

Garcia Neto, M. Programa prático para formulação de rações/frangos de corte PPFR; 2008 [cited 2017 Mar 22]. Available from: http://www. foa.unesp. br/downloads/categoria. asp? CatCod=4\&SubCatCod=138.
Gonzalez-Esquerra R, Leeson S. Effects of acute versus chronic heat stress on broiler response to dietary protein. Poultry Science 2005;84:15621569.

Ludtke C B, Ciocca J R P, Dandin T, Barbalho P C, Vilela J A. Abate humanitário de aves. Rio de janeiro: WSPA; 2010.

Mongin P. Recent advances in dietary anion-cation balance: application in poultry. The proceednigs of the nutrition society 1981;40(3):285-294.

Mujahid A. Nutritional strategies to maintain efficiency and production of chickens under high environmental temperature. Japan Poultry Science Association 2011;48(3):145-154.

Ngoka DA, Froning GW. Effect of free struggle and preslaughter excitement on color of turkey breast muscles. Poultry Science 1982;61(11):22912293.

Northcutt JK, Foegeding EA, Edens FW. Water-holding properties of thermally preconditioned chicken breast and leg meat. Poultry Science $1994 ; 73(2): 308-316$.

Oliveira PM, Faria Junior MJA, Garcia Neto M. Estratégias para minimizar os efeitos de um ambiente térmico adverso para frangos de corte. Arquivo Brasileiro de Medicina Veterinária e Zootecnia 2016;68(3):739-747.

Plavnik I, Yahav S. Effect of environmental temperature on broiler chickens subjected to growth restriction at an early age. Poultry Science $1998 ; 77(6): 870-872$.

SAS Institute. Users guide: statistics. 5th ed. Cary; 2000.

Silva DJ, Queiroz AC. Análise de alimentos - métodos químicos e biológicos. 3ed. Viçosa: Ed.UFV; 2002. p. 235.

Smith DP, Northcutt JK. Pale poultry muscle syndrome. Poultry Science 2009;88(7):1493-1496.

Smith MO, Teeter RG. Potassium balance of the 5 to 8-week-old broiler exposed to constant heat or cycling high temperature stress and the effects of supplemental potassium chloride on body weight gain and feed efficiency. Poultry Science 1987;66(3):487-492.

Souza BB, Bertechini AG, Teixeira AS, Lima JAF, Freitas RTF. Efeito da suplementação de cloreto de potássio na dieta sobre o equilíbrio ácido-básico e o desempenho de frangos de corte no verão. Ciência Agrotecnologia 2002;26(6):1297-1304.

Tabler GT, Berry IL, Xin H, Barton TL. Spatial distribution of mortality in broiler flocks. The Journal of Applied Poultry Research 2002;11(4):388396.

Teeter RG, Smith MO, Owens FN, Arp SC, Sangiah S, Breazile JE. Chronic heat stress and respiratory alkalosis: ocorrence and treatment in broiler chicks. Poultry Science 1985;64(6):1060-1064.

Vale MM, Moura DJ, Nääs IA, Pereira DF. Characterization of heat waves affecting mortality rates of broilers between 29 days and market age. Brazilian Journal of Poultry Science 2010;12(4):279-285.

Woelfel RL, Owens CM, Hirschler EM, Martinez-Dawson R, Sams AR. The Characterization and Incidence of Pale, Soft, and Exudative Broiler Meat in a Commercial Processing Plant. Poultry Science 2002; 81(4):579-584.

Xie J, Tang L, Lu L, Zhang L, Lin X, Liu H, Odle J, Luo X. Effects of acute and chronic heat stress on plasma metabolites, hormones and oxidant status in restricdly fed broiler breeders. Poultry Science 2015; 94(1):1635-1644.

Yahav S, McMurtry JP. Thermotolerance acquisition in broiler chickens by temperature conditioning early in life - the effect of timing and ambient temperature. Poultry Science 2001; 80(12):1662-1666.

Zaboli GR, Rahimi S, Shariatmadari F, Torshizi MAK, Baghbanzadeh A, Mehri M. Thermal manipulation during pre and post-hatch on thermotolerance of male broiler chickens exposed to chronic heat stress. Poultry Science 2017; 96(2):478-485. 